\title{
Temporal concentration changes of beryllium-7 and lead-210 in ground level air in Serbia
}

\author{
Marija M. Janković, Dragana J. Todorović, Jelena D. Nikolić, Milica M. Rajačić, Gordana K. Pantelić, \\ Nataša B. Sarap
}

University of Belgrade, Vinča Institute of Nuclear Sciences, Radiation and Environmental Protection Department, P.O. Box 522, 11001 Belgrade, Serbia

\begin{abstract}
${ }^{7} \mathrm{Be},{ }^{210} \mathrm{~Pb}$ and ${ }^{137} \mathrm{Cs}$ activity concentrations in ground level air at five monitoring stations (MS Vinča, Zeleno Brdo, Zaječar, Vranje and Zlatibor) in Serbia were determined during the period from May 2011 to September 2012, as part of the Serbian monitoring project. Activity of the radionuclides in air was determined on a HPGe detector (Canberra, relative efficiency $20 \%$ ) by standard gamma spectrometry. Concentrations of cosmogenic ${ }^{7} \mathrm{Be}$, ranged from 1.5 to $8.8 \mathrm{mBq} \mathrm{m}^{-3}$ and exhibited maxima in the spring/summer period. The maximum concentrations for ${ }^{210} \mathrm{~Pb}$ were generally observed in the fall for all investigated locations, and concentrations were in the range $3.6 \times 10^{-4}-30 \times 10^{-4} \mathrm{~Bq} \mathrm{~m}^{-3}$. The activity concentrations of anthropogenic ${ }^{137} \mathrm{Cs}$ in ground level air, during the observed period, were in the range $0.3-8 \mu \mathrm{Bq} \mathrm{m}{ }^{-3}$. The variations in ${ }^{7} \mathrm{Be} /{ }^{210} \mathrm{~Pb}$ activity ratio for the investigated stations are also presented.
\end{abstract}

Keywords: Radioactivity, ground level air, ${ }^{7} \mathrm{Be},{ }^{210} \mathrm{~Pb},{ }^{137} \mathrm{Cs}$.

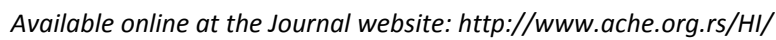

Nuclear weapon tests conducted in the atmosphere and releases of radioactive material from nuclear facilities are the main causes of man-made radioactive contamination in the human environment. Once released in the atmosphere, long-range atmospheric transport processes can cause widespread distribution of radioactive matter or they might, as in the case of Chernobyl accident, originate from a single point. The resulting fallout consisting of short- and long-lived radionuclides, eventually affects humans either directly or indirectly by entering the food chain through plants and animals. In both cases, fallout causes a health hazard to the population, either through direct irradiation or consumption of contaminated food products. Potential danger of radioactive particles inhalation must be determined and controlled based on levels and types of radioactivity. Accurate data on natural radionuclide concentration in air is essential, not only because exposure to natural radionuclides greatly contributes to radiation exposure [1], but also because this information contributes to studies of atmospheric circulation of air masses [2].

Particle reactive radionuclides such as ${ }^{7} \mathrm{Be}$ and ${ }^{210} \mathrm{~Pb}$ have been used as atmospheric tracers for studying environmental processes such as cloud scavenging and precipitation $[3,4]$, aerosol transit and residence times

Correspondence: M.M. Janković, University of Belgrade, Vinča Institute of Nuclear Sciences, Radiation and Environmental Protection Department, P.O. Box 522, 11001 Belgrade, Serbia.

E-mail: marijam@vinca.rs

Paper received: 20 March, 2013

Paper accepted: 15 April, 2013

\section{SCIENTIFIC PAPER}

UDC 502.3(497.11):504.5:546.45

Hem. Ind. 68 (1) 83-88 (2014)

doi: 10.2298/HEMIND130320031J in the troposphere $[5,6]$, aerosol deposition velocities [7-10] and the fate of pollutants [11].

${ }^{7} \mathrm{Be}$ is a radioactive element (half-life 53.3 days) produced by cosmic rays in spallation processes with light elements ( $\mathrm{N}, \mathrm{O}$ and $\mathrm{C}$ ), in the lower stratosphere $(\sim 70 \%)$ and the upper troposphere $(-30 \%)$. Following production, ${ }^{7} \mathrm{Be}$ is promptly attached to aerosols with a diameter of $0.3-0.6 \mathrm{~mm}$ whose residence time in the atmosphere is around 20 days [12]. In the troposphere, apart from its decay, ${ }^{7} \mathrm{Be}$ is removed by wet deposition (the major mechanism for removal) and dry deposition. In ground level air, the residence time of ${ }^{7} \mathrm{Be}$ is around 10 days [13].

Natural ${ }^{210} \mathrm{~Pb}$ (half-life 22.3 years) is an effective tracer of the history of continental surface air masses and could be used to identify soil aerosol sources. As a member of ${ }^{222} \mathrm{Rn}$ decay series, it is a decay product of primordial ${ }^{238} \mathrm{U}$, but can also be found as a product of coal combustion and nuclear explosions in very small amounts $(<1 \%)$. Concentrations of ${ }^{210} \mathrm{~Pb}$ in air exhibit maxima during autumn, which may be attributed to an increased emanation of radon [14,15]. Deposition of ${ }^{210} \mathrm{~Pb}$ also varies with geographic position and is generally found in higher concentrations at mid-latitudes. Still, emanation of radon and therefore concentrations of ${ }^{210} \mathrm{~Pb}$ in surface air are affected by many factors, as atmospheric pressure, temperature inversion, vegetation, snow coverage, etc.

Since ${ }^{7} \mathrm{Be}$ is of cosmogenic origin and its production rate is high in the upper troposphere and decreases with atmospheric depth, its concentrations in air increase with altitude. On the contrary, the concen- 
trations of ${ }^{210} \mathrm{~Pb}$ in air decrease with elevation from the ground, due to its higher production rate in the lower troposphere.

The fission product ${ }^{137} \mathrm{Cs}$ (half-life 30 years) is a reliable indicator of anthropogenic pollution caused by nuclear weapon atmospheric tests and local nuclear power plant accidents. Concentrations of ${ }^{137} \mathrm{Cs}$ in the ground level air in the 1990s were in the order of $\mu \mathrm{Bq}$ $\mathrm{m}^{-3}$. Seasonal variation in the ${ }^{137} \mathrm{Cs}$ content in air is a valid indicator of the STE processes (stratosphere-totroposphere exchange). The concentration pattern exhibits one or two maxima in late spring/early summer and winter. The summer maximum is due to STE, whereas the winter maximum is attributed to soil dust resuspension in air from the Chernobyl fallout $[16,17]$.

Due to high population density, heavy traffic and industrial plants located in the outskirts, urban areas are exposed to severe air pollution. In the last decade, air radioactivity monitoring in urban areas has become a part of the pollution monitoring program in most of the European countries. This paper presents the results of the comparative study of air radioactivity monitoring at five sites in Serbia from May 2011 to September 2012.

\section{EXPERIMENTAL}

Aerosol samples were collected on filter papers (Whatman 41, $15 \mathrm{~cm} \times 25 \mathrm{~cm}$ in diameter, relative efficiency for deposited dust $82 \%$ ) by constant flow rate samplers (air flow $40-60 \mathrm{~m}^{3} \mathrm{~h}^{-1}$, average daily volume in the interval $720-1440 \mathrm{~m}^{3}$ ). The filter papers were then ashed at temperatures below $400{ }^{\circ} \mathrm{C}$ and a monthly composite sample containing 30-31 daily filters was formed (volume in the interval $30 \times 10^{3}-60 \times 10^{3} \mathrm{~m}^{3}$ ) [18]. The activity of ${ }^{7} \mathrm{Be},{ }^{210} \mathrm{~Pb}$ and ${ }^{137} \mathrm{Cs}$ was determined on a HPGe detector (Canberra relative efficiency 20\%) by standard gamma spectrometry. Detector calibration was performed using secondary reference radioactive material in the geometry of plastic containers, vials, which were obtained from the primary reference radioactive materials, Czech metrological Institute, Praha, OL-9031-116/8, type ERX, with the total activity of $114.9 \mathrm{kBq}$ on 03.03.2008 $\left({ }^{241} \mathrm{Am},{ }^{109} \mathrm{Cd},{ }^{139} \mathrm{Ce},{ }^{57} \mathrm{Co}\right.$, ${ }^{60} \mathrm{Co},{ }^{88} \mathrm{Y},{ }^{113} \mathrm{Sn},{ }^{85} \mathrm{Sr}{ }^{137} \mathrm{Cs}$ and $\left.{ }^{210} \mathrm{~Pb}\right)$. The detection threshold of ${ }^{7} \mathrm{Be}$ in air was $5 \times 10^{-6}$ and $5 \times 10^{-6} \mathrm{~Bq} \mathrm{~m}^{-3}$ for ${ }^{210} \mathrm{~Pb}$ and $5 \times 10^{-7} \mathrm{~Bq} \mathrm{~m}{ }^{-3}$ for ${ }^{137} \mathrm{Cs}$. Counting time intervals were $60000 \mathrm{~s}$. The background spectrum was regularly recorded prior to or after sample counting. The combined measurement uncertainty of the results was calculated at the $95 \%$ level of confidence $(k=2)$.

\section{RESULTS AND DISCUSSION}

In the analyzed samples levels of ${ }^{7} \mathrm{Be},{ }^{210} \mathrm{~Pb}$ and ${ }^{137} \mathrm{Cs}$ were detected. Concentrations of these radionuclides in ground level air at different locations in Serbia during the period May 2011-September 2012 are presented in Figures 1-3, respectively.

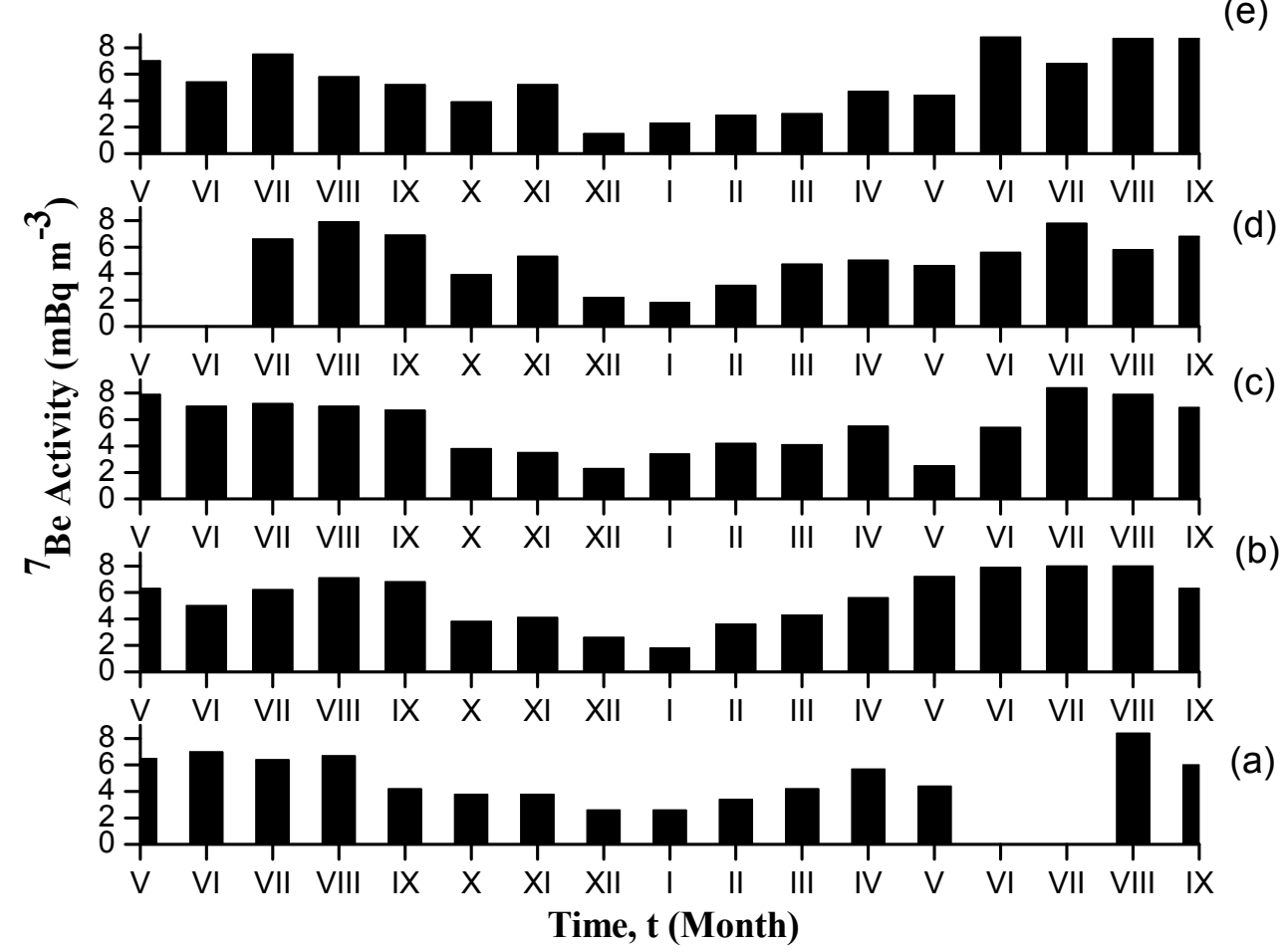

Figure $1 .{ }^{7}$ Be activity in the ground level air at: a) Vinča, b) Zeleno Brdo, c) Zaječar, d) Vranje and e) Zlatibor. 


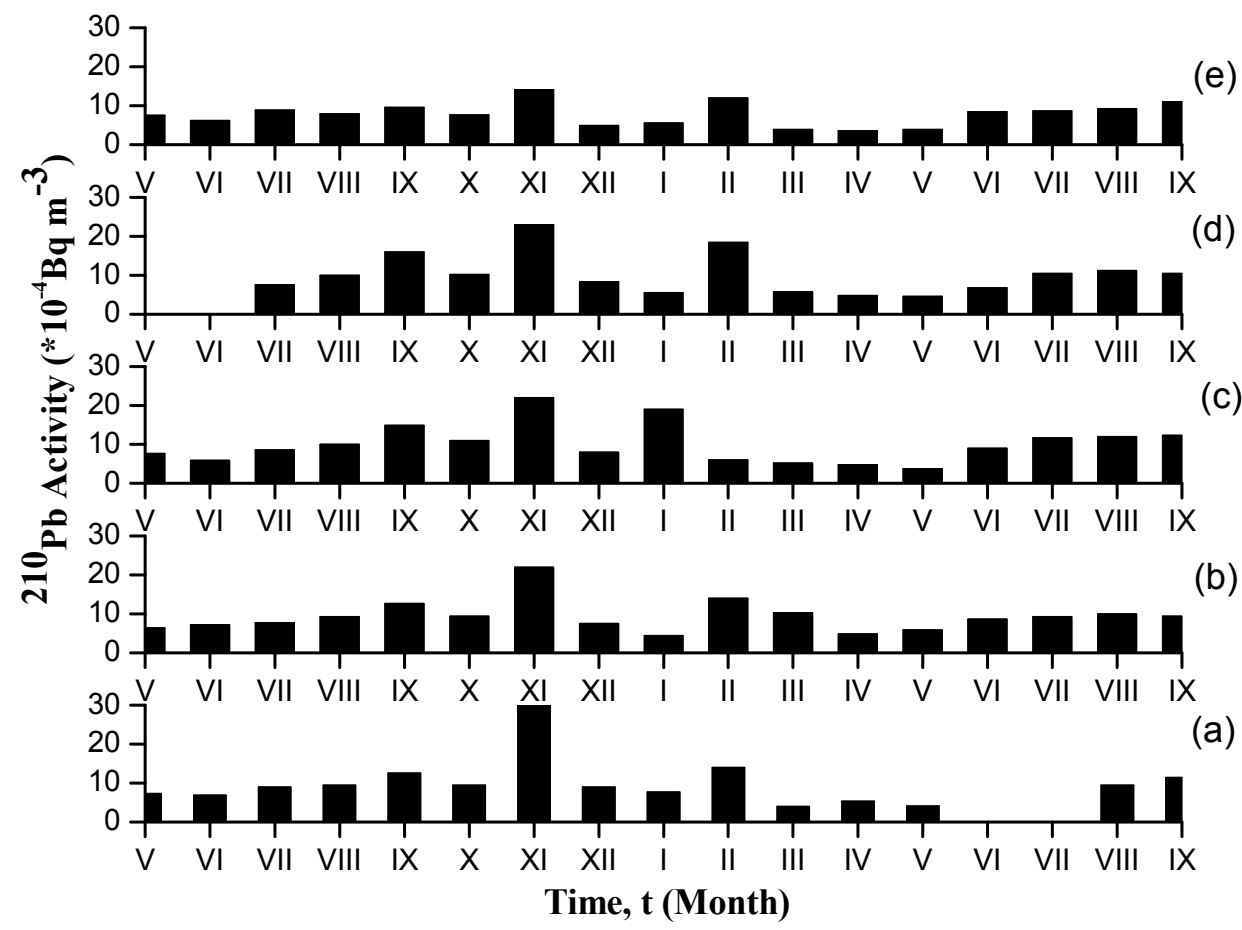

Figure 2. ${ }^{210} \mathrm{~Pb}$ activity in the ground level air at: a) Vinča, b) Zeleno Brdo, c) Zaječar, d) Vranje and e) Zlatibor.

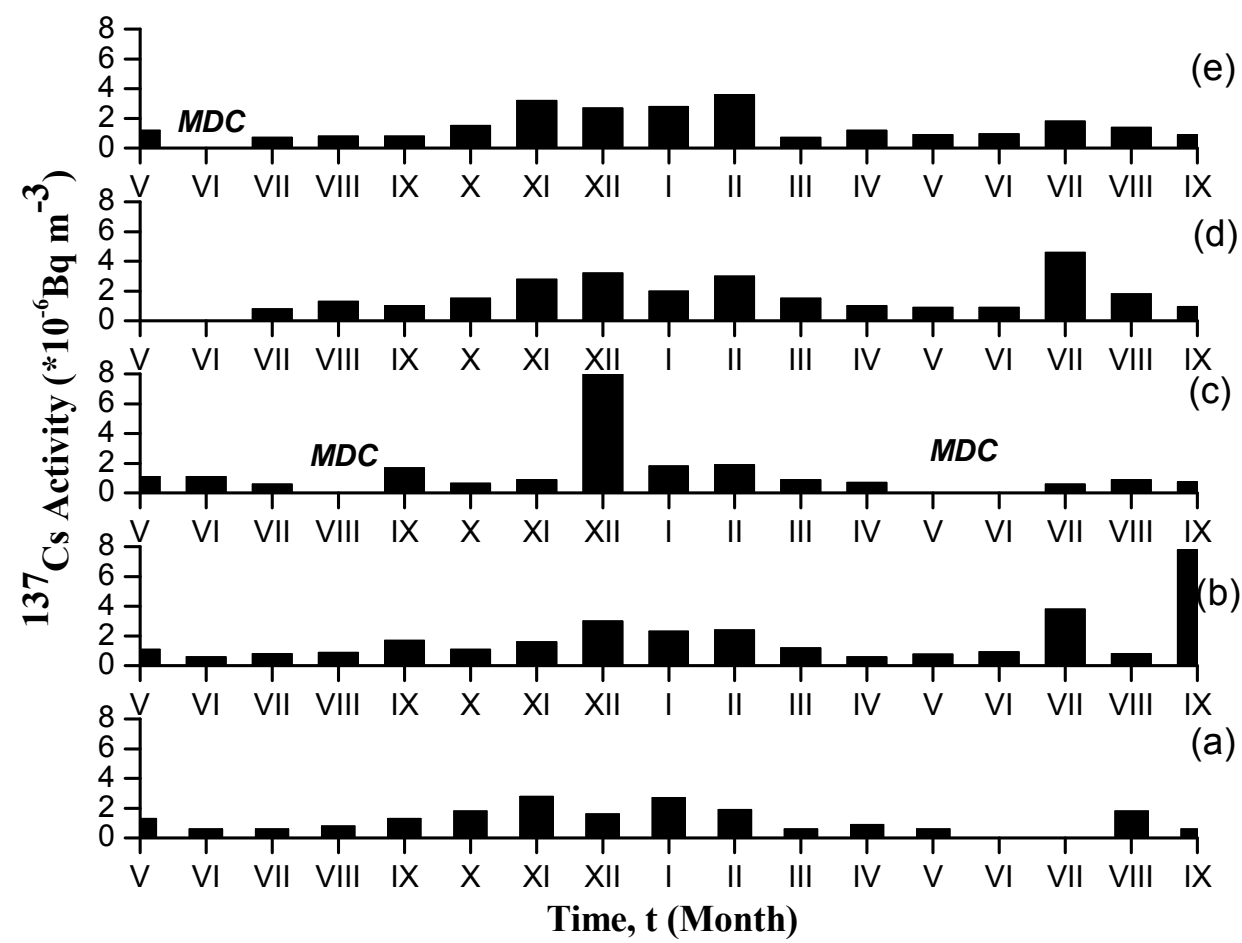

Figure $3 .{ }^{137}$ Cs activity in the ground level air at: a) Vinča, b) Zeleno Brdo, c) Zaječar, d) Vranje and e) Zlatibor.

Concentrations of ${ }^{7} \mathrm{Be}$ in air were in the range of 1.5 (Zlatibor, XII 2011)-8.8 $\mathrm{mBq} \mathrm{m}^{-3}$ (Zlatibor, VI 2012), and exhibited maximum in spring/summer and minimum in winter (Figure 1). This variation of ${ }^{7} \mathrm{Be}$ is similar for all investigated locations. The highest ${ }^{7} \mathrm{Be}$ activity concentrations during the warm season in the investigated region were attributed to more efficient vertical transport of air masses during that period. A phenomenon that advocates for the observed high values during summer is the elevation of the tropopause during the warm summer months at midlatitudes [19]. During the winter months, when temperatures are low and atmo- 
sphere is more "stable", the tropopause height is lower and therefore the concentrations of ${ }^{7} \mathrm{Be}$ in surface air are low.

These results obtained for ${ }^{7} \mathrm{Be}$ at five investigated locations in Serbia are in good agreement with other Belgrade studies $[20,21]$ and with results obtained at other locations in Europe. For example, Durana et al. [22] presented 1977-1994 results for the Bratislava atmosphere, showing that the ${ }^{7} \mathrm{Be}$ activity rarely exceeded $6 \mathrm{mBq} \mathrm{m}^{-3}$, and that it reached its maximum in June. Likewise, during period 1993-1997 Azahra et al. [23] measured ${ }^{7} \mathrm{Be}$ in Granada, and demonstrated that the highest values were reached in summer. Similar results for ground level ${ }^{7} \mathrm{Be}$ were shown by Irlweck et al. [24] as well as other studies [12,25,26].

The average concentration per month of $\mathrm{Be}-7$ in Europe is usually several $\mathrm{mBq} \mathrm{m}^{-3}$. For example, in Thessaloniki (Greece) the average monthly concentration of $\mathrm{Be}-7$ is in the range $1-10 \mathrm{mBq} \mathrm{m}^{-3}$. The listed countries are located at similar geographical latitude [5,22]. Feely et al. [27] reported for the same latitude in New York City $\left(40^{\circ} 73^{\prime} \mathrm{N}\right) 4.55 \mathrm{mBq} \mathrm{m}^{-3}$ for ${ }^{7}$ Be averaging for the period 1970-1985, while McNeary and Baskaran [28] at a site in the southwest area of Detroit, Michigan $\left(42^{\circ} 25^{\prime} \mathrm{N}\right), 175 \mathrm{~m}$ above mean sea level and $1 \mathrm{~m}$ above ground reported $4.83 \mathrm{mBq} \mathrm{m}^{-3}$ for ${ }^{7} \mathrm{Be}$, averaged for the period October 1999-February 2001. It must be noted that the environmental concentration of ${ }^{7} \mathrm{Be}$ in the temperate zones is about $3 \mathrm{mBq} \mathrm{m}^{-3}$ in the surface air [29].
Contents of ${ }^{210} \mathrm{~Pb}$ vary from $3.6 \times 10^{-4} \mathrm{~Bq} \mathrm{~m}{ }^{-3}$ (Zlatibor, IV 2012) to $30 \times 10^{-4} \mathrm{~Bq} \mathrm{~m}^{-3}$ (Vinča, XI 2011) (Figure 2). The maximal ${ }^{210} \mathrm{~Pb}$ values were observed during November at all locations, while the minimum was observed during March-May period. The higher values of ${ }^{210} \mathrm{~Pb}$ during November might be attributed to the frequent inversion conditions of the surface air layers, resulting in a build-up of radon and its decay products in ground-level air, while the relative low values during December might be due to the low emanation of radon from the frozen or snow-covered soil. The minimal values of ${ }^{210} \mathrm{~Pb}$ concentrations in ground level air during the spring might reflect high washout. The obtained values of ${ }^{210} \mathrm{~Pb}$ concentrations during the summer period showed a weak increase, although the higher air mixing within the troposphere during the warm summer months was expected to deplete ${ }^{210} \mathrm{~Pb}$ in ground-level air, since its concentrations in the air decreased with elevation from the earth's surface.

The obtained values for ${ }^{210} \mathrm{~Pb}$ in the ground level air at different locations presented in this paper are in good agreement with values for ${ }^{210} \mathrm{~Pb}$ obtained in Belgrade during 1985-1996 [30], 1996-2001 [21] and 2004-2009 [31].

The activity concentrations of anthropogenic ${ }^{137} \mathrm{Cs}$ in ground level air, during the observed period, were at level $<\mathrm{MDC}-8 \mu \mathrm{Bq} \mathrm{m}{ }^{-3}$ (Figure 3). The content of ${ }^{137} \mathrm{Cs}$ in ground level air presented in this paper is lower than the values of ${ }^{137} \mathrm{Cs}$ in the Belgrade city area during 1991-1996 [32], with maximum in the spring/summer

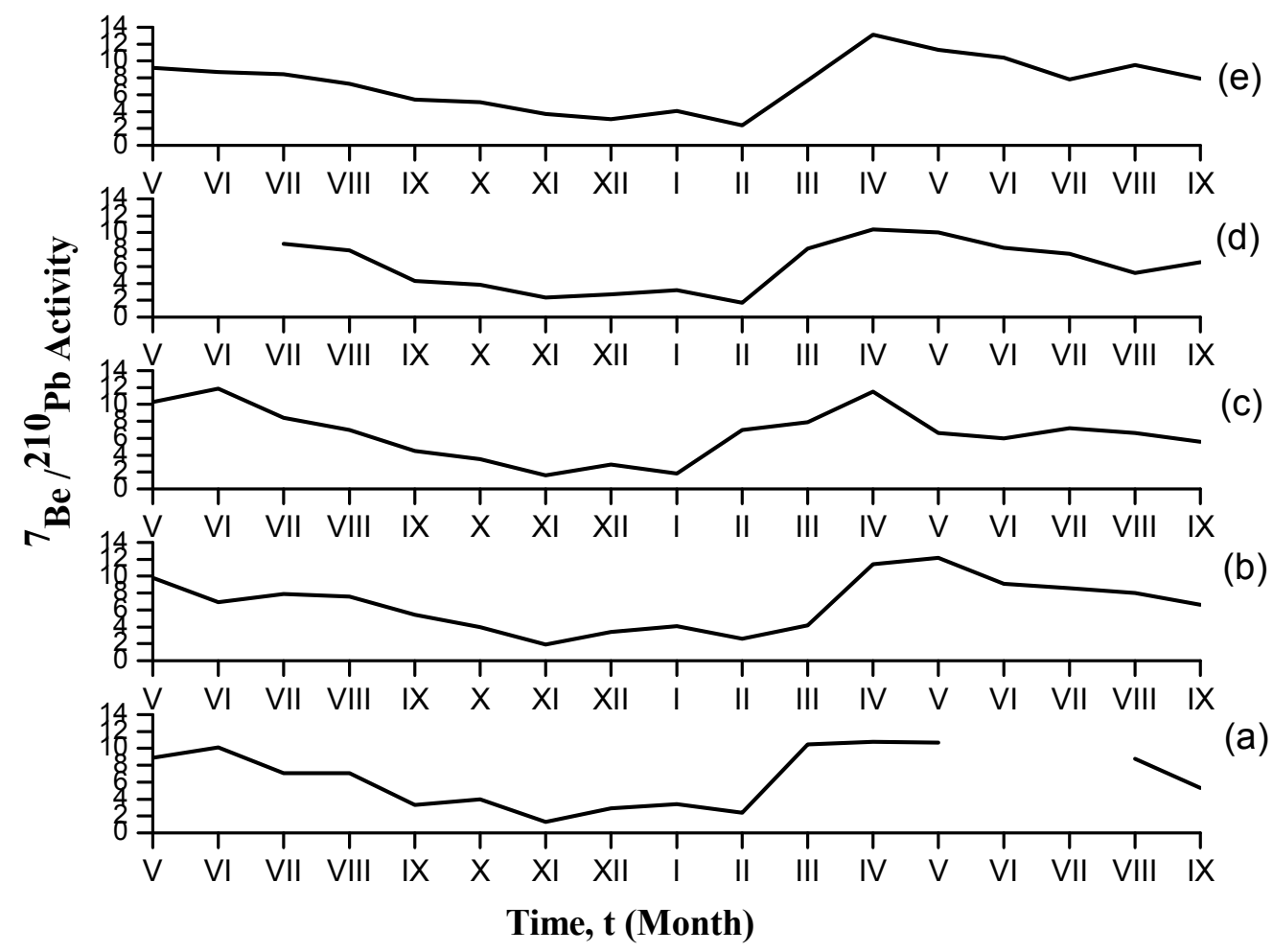

Figure 4. Temporal variation of $\left.{ }^{7} \mathrm{Be}\right|^{210} \mathrm{~Pb}$ concentration ratio. 
period and another pronounced maximum during winter months (XI-II). The high concentration of ${ }^{137} \mathrm{Cs}$ in the winter is due to agricultural activities in the surrounding fields that induced local surface dust resuspension effect, while high concentration in the summer is due to air exchange weather conditions [32].

The variations in ${ }^{7} \mathrm{Be} /{ }^{210} \mathrm{~Pb}$ activity ratio for the five investigated locations are presented in Figure 4 . The ${ }^{7} \mathrm{Be} /{ }^{210} \mathrm{~Pb}$ ratios were in the range of $1.3-10.8$ (Vinča), 1.9-12.2 (Zeleno Brdo), 1.6-11.9 (Zaječar), 1.7-10.4 (Vranje) and 2.4-13.1 (Zlatibor), with spring maximums and late fall/winter minimums.

\section{CONCLUSIONS}

Time dependent activity of ${ }^{7} \mathrm{Be},{ }^{210} \mathrm{~Pb}$ and ${ }^{137} \mathrm{Cs}$, measured in ground level air at five different locations in Serbia during May 2011 to September 2012 are presented. The typical pattern of seasonal variations was observed for ${ }^{7} \mathrm{Be}$ and ${ }^{210} \mathrm{~Pb}$ activity concentrations. The obtained values for ${ }^{7} \mathrm{Be}$ concentrations in ground level air show a fluctuation which has oscillatory characteristics with enhanced activity in spring-summer months. This fluctuation is likely related to the seasonal thinning of tropopause, which facilitates and enhances the stratosphere - troposphere vertical air mass mixing. Inverse trend was obtained for ${ }^{210} \mathrm{~Pb}$ with the highest value during November for all locations. The obtained concentrations of ${ }^{137} \mathrm{Cs}$ are in the $\mu \mathrm{Bq} \mathrm{m}{ }^{-3}$ range. The time dependence behavior of ${ }^{7} \mathrm{Be} /{ }^{210} \mathrm{~Pb}$ concentration ratio shows that higher intensity of vertical convection of air during warm season results in air - masses transfer from higher altitudes.

\section{Acknowledgment}

The investigation was partially supported by the Ministry of Education, Science and Technological Development of the Republic of Serbia under the Project III43009.

\section{REFERENCES}

[1] R. L. Kathren, Radioactivity in the environment, sources, distribution and surveillance, University of Washington, Harwood Academic Publishers, Newark, NJ, 1984.

[2] E. Gomez, F. Garcias, M. Casas, V. Cerda, Determination of natural gamma emitters in surfaces air, J. Environ. Anal. Chem. 56 (1994) 327-335.

[3] D.M. Koch, D.J. Jacob, W.C. Graustein, Vertical transport of tropospheric aerosols as indicated by ${ }^{7} \mathrm{Be}$ and ${ }^{210} \mathrm{~Pb}$ in a chemical tracer model. J. Geophys. Res. 101 (1996) 18651-18666.

[4] H. Liu, D. Jacob, I. Bey, R. Yantosca, Constraints from ${ }^{210} \mathrm{~Pb}$ and ${ }^{7} \mathrm{Be}$ on wet deposition and transport in a global three-dimentional chemical tracer model driven by assimilated meteorological fields. J. Geophys. Res. 106 (2001) 12109-12128.
[5] C. Papastefanou, A. Ioannidou, S. Stoulos, M. Manolopoulou, Atmospheric deposition of cosmogenic ${ }^{7} \mathrm{Be}$ and ${ }^{137}$ Cs from fallout of the Chernobyl accident, Sci. Total Environ. 170 (1995) 151-156.

[6] R. Winkler, F. Dietl, G. Frank, J. Tschiersch, Temporal variations of ${ }^{7} \mathrm{Be}$ and ${ }^{210} \mathrm{~Pb}$ size distributions in ambient aerosol. Atmos. Environ. 32 (1998) 983-991.

[7] J.A. Young, W.B. Silker, Aerosol deposition velocities on the Pacific and Atlantic Oceans calculated from ${ }^{7} \mathrm{Be}$ measurements, Earth. Planet. Sci. Lett. 50 (1980) 92$-104$.

[8] E.A. Crecelius, Prediction of marine atmospheric deposition rates using ${ }^{7} \mathrm{Be}$ deposition velocities, Atmos. Environ. 15 (1981) 579-582.

[9] K.K. Turekian, L.K. Benninger, E.P. Dioan, ${ }^{7} \mathrm{Be}$ and ${ }^{210} \mathrm{~Pb}$ total deposition fluxes at New Haven, Connecticut and at Bermuda, J. Geophys. Res. 88 (1983) 5411-5415.

[10] G. Lujaniene, Study of removal processes of ${ }^{7} \mathrm{Be}$ and ${ }^{137} \mathrm{Cs}$ from the atmosphere. Chechoslovak, J. Phys. 53 (2003) S57-S65.

[11] C. Papastefanou, A. Ioannidou, Influence of air pollutants in the ${ }^{7} \mathrm{Be}$ size distribution of atmospheric aerosols, Aerosol Sci.Technol. 24 (1996) 102-106.

[12] J.S. Gaffney, N.A. Marley, M.M. Cunningham, Natural radionuclides in fine aerosols in the Pittsburgh Area, Atmos. Environ. 38 (2004) 3191-3200.

[13] A. Baeza, L.M. del Río, A. Jiménez, C. Miró, J.M. Paniagua, M. Rufo, Analysis of the temporal evolution of atmospheric ${ }^{7} \mathrm{Be}$ as a vector of the behavior of other radionuclides in the atmosphere, J. Radioanal. Nucl. Chem. 207 (1996) 331-344.

[14] K. Hirose, T. Honda, S. Yagashita, Y. Igaradhi, M. Aoyama, Deposition behaviors of ${ }^{210} \mathrm{~Pb}$, and thorium isotopes observed in Tsukuba and Nagasaki Japan, Atmos. Environ. 38 (2004) 6601-6608.

[15] A. loanidou, C. Papastefanou, ${ }^{7} \mathrm{Be},{ }^{22} \mathrm{Na}$ and ${ }^{210} \mathrm{~Pb}$ in the atmosphere at mid latitude $40^{\circ} \mathrm{N}$, Nucleus 34 (1997) 111-115.

[16] R.J. Larsen, C. Sanderson, J. Kada, EML surface air sampling programme, New York: US Energy Dept., 1995.

[17] G. Manic, S. Petrovic, V. Manic, D. Popovic, D. Todorovic, Radon concentrations in a spa in Serbia, Environ. Int. 32 (2006) 533-537.

[18] D. Popovic, D. Todorovic, V. Spasic Jokic, G. Djuric, Air Radioactivity monitoring in Serbia, in Environmetal Technologies: New Developements, Ed. Burcu Ozkaraova Gungor, Publ. I-Tech Inc, Vienna, 2007, pp. 147$-166$.

[19] P.F. Gustafson, M.A. Kerrigan, S.S. Brar, Comparison of beryllium-7 and caesium-137 radioactivity in ground level air, Nature 191 (1961) 454-456.

[20] Report on the levels of exposure of general public to environmental ionizing radiation in Rebublic of Serbia, Serbian Radiation Protection and Nuclear Safety Agency, Belgrade, 2011.

[21] D. Todorović, D. Popović, G. Djurić, M. Radenković, ${ }^{7} B e$ to ${ }^{210} \mathrm{~Pb}$ concentration ratio in ground level air in Belgrade area, J. Eniviron. Radioact. 79 (2005) 297-307. 
[22] L. Durana, M. Chudy, L. Masarik, Investigation of ${ }^{7} \mathrm{Be}$ in the Bratislava atmosphere, J. Radioanal. Nucl. Ch. 207 (1996) 345-356.

[23] M. Azahra, J. J. López-Peñalver, M. A. Camacho-García, C. Gonzáles-Gómez, T. El Bardouni, H. Boukhal, Atmospheric concentration of ${ }^{7} \mathrm{Be}$ and ${ }^{210} \mathrm{~Pb}$ in Granada, Spain, J. Radioanal. Nucl. Chem. 261 (2004) 401-405.

[24] K. Irlweck, K. Hinterdorfer, V. Karg, Beryllium-7 and Ozone correlations in surface atmosphere, Naturwiessenschaften 84 (1997) 353-356.

[25] F. Cannizzaro, G. Greco, M. Raneli, M. C. Spitale, E. Tomarchio, Behaviour of ${ }^{7} \mathrm{Be}$ air concentration observed during a period of 13 years and comparison with sun activity, Nucl. Geophys. 9 (1995) 597-607.

[26] C. Dueñas, M. C. Fernández, E. Liger, J. Carretero, Gross alpha, gross beta activities and ${ }^{7} \mathrm{Be}$ concentrations in surface air, analysis of their variations and prediction model, Atmos. Environ. 33 (1999) 3705-3715.
[27] H.W. Feely, R.J. Larsen, C.G. Sanderson, Factors that cause seasonal variations in Beryllium-7 concentrations in surface air, J. Environ. Radioactivity 9 (1989) 223-249.

[28] D. McNeary, M. Baskaran, Depositional characteristics of ${ }^{7} \mathrm{Be}$ and ${ }^{210} \mathrm{~Pb}$ in Southeastern Michigan, J. Geophys. Res. 108 (D7) (2003) 4210.

[29] UNSCEAR, lonizing Radiation: Sources and Biological Effects, United Nations Scientific Committee on the Effects of Atomic Radiation, United Nations, New York, 1982.

[30] D. Todorović, D. Popović, G. Đurić, M. Radenković, ${ }^{210} \mathrm{~Pb}$ in ground-level air in Belgrade city area, Atmos. Environ. 34 (2000) 3245-3248.

[31] D. Todorović, D. Popović, J. Nikolić, J. Ajtić, Radioactivity monitoring in ground level air in Belgrade urban area, Radiat. Prot. Dosim. 142 (2010) 308-313.

[32] D. Todorović, D. Popović, G. Đurić, Concentration measurements of ${ }^{7} \mathrm{Be}$ and ${ }^{137} \mathrm{Cs}$ in ground level air in the Belgrade city area, Environ. Int. 25 (1999) 59-66.

\section{IZVOD}

\section{AKTIVNOST BERILIJUMA-7 I OLOVA-210 U PRIZEMNOM SLOJU ATMOSFERE U SRBIJI}

Marija M. Janković, Dragana J. Todorović, Jelena D. Nikolić, Milica M. Rajačić, Gordana K. Pantelić, Nataša B. Sarap

Univerzitet u Beogradu, Institut za nuklearne nauke Vinča, Laboratorija za zaštitu od zračenja i zaštitu životne sredine, p. pr. 522, 11001 Beograd, Srbija

\section{(Naučni rad)}

Prirodni radionuklidi ${ }^{7} \mathrm{Be} \mathrm{i}^{210} \mathrm{~Pb}$ često se koriste kao atmosferski traseri u cilju izučavanja fizičkih procesa u atmosferi kao što su formiranje oblaka i padavina, transport i vreme života aerosola u troposferi, brzina depozicije, i evolucija zagađivača u atmosferi. Sa druge strane, fisioni produkt ${ }^{137} \mathrm{Cs}$ je pouzdani indikator antropogenog zagađenja, izazvanog vazdušnim nuklearnim probama i akcidentima u nuklearnim elektranama. Zbog velike gustine naseljenosti, gustog saobraćaja i industrije, urbane oblasti su izložene ozbiljnom zagađenju vazduha. $U$ poslednjoj deceniji, monitoring radioaktivnosti vazduha u urbanim sredinama je postao deo opšteg programa monitoringa životne sredine u većini evropskih zemalja. Ovaj rad predstavlja rezultate komparativne studije radioaktivnosti u vazduhu u pet gradova u Srbiji od maja 2011. do septembra 2012. Koncentracije aktivnosti ${ }^{7} \mathrm{Be},{ }^{210} \mathrm{~Pb} \mathrm{i}{ }^{137} \mathrm{Cs}$ u uzorcima prizemnog sloja vazduha na pet meteoroloških stanica (MS Vinča, Zeleno Brdo, Zaječar i Zlatibor) su određene na HPGe detektoru (Canberra, relativna efikasnost 20\%) metodom gama spektrometrije. Koncentracije aktivnosti kosmogenog ${ }^{7} \mathrm{Be}$ su se kretale $\mathrm{u}$ rasponu od 1.5 do 8.8 $\mathrm{mBq} \mathrm{\textrm {m } ^ { - 3 }}$ uz izražen maksimum u proleće/leto. Maksimalne koncentracije aktivnosti ${ }^{210} \mathrm{~Pb}$ su dobijene $\mathrm{u}$ jesen na svim ispitivanim lokacijama, a opseg rezultata je bio $3.6 \times 10^{-4}-30 \times 10^{-4} \mathrm{~Bq} \mathrm{~m}^{-3}$. Oba ova radionuklida ispoljavaju tipične sezonske varijacije. Vremenske varijacije odnosa ${ }^{7} \mathrm{Be} /{ }^{210} \mathrm{~Pb}$ su takođe ispitivane i pokazuju maksimum u leto i minimum u zimskom periodu. Ovi ekstremumi su posledica jače vertikalne konvekcije vazduha u leto odnosno veće stabilnosti i manjeg vertikalnog mešanja vazdušnih masa u zimu. Koncentracija aktivnosti prizvedenog radionuklida ${ }^{137} \mathrm{Cs}$ u posmatranom periodu je bila $0.3-8 \mu \mathrm{Bq} \mathrm{m}^{-3}$, sa izraženim maksimumima u letnjem i zimskom periodu. Visoka koncentracija ${ }^{137} \mathrm{Cs}$ u zimskom periodu je posledica poljoprivrednih aktivnosti u okolini ispitivanih lokacija, koje dovode do povećane lokalne resuspenzije prašine, dok je letnji maksimum uslovljen razmenom i mešanjem vazdušnih masa, tipičnom za vremenske prilike u ovom godišnjem dobu.
Ključne reči: Radioaktivnost - Prizemni sloj atmosfere $\bullet{ }^{7} \mathrm{Be} \bullet{ }^{210} \mathrm{~Pb} \bullet{ }^{137} \mathrm{Cs}$ 